ORIGINAL ARTICLE

\title{
Simultaneous selection of cupuassu tree and Brazilian mahogany genotypes in an agroforestry system in Pará state, Brazil
}

\author{
Rafael Moysés ALVES ${ }^{1}$, Saulo Fabrício da Silva CHAVES ${ }^{2 *}$, Marcos André Piedade GAMA³ $^{3}$ \\ Jack Loureiro PEDROZA NETO 3 , Thalita Gomes dos SANTOS ${ }^{4}$ \\ Empresa Brasileira de Pesquisa Agropecuária, Unidade Amazônia Oriental, Travessa Dr. Enéas Pinheiro, s/n, CEP 66095-903, Belém, PA, Brazil \\ 2 Universidade Federal de Viçosa, Av. Peter Henry Rolfs, s/n, Campus Universitário, CEP 36570-900, Viçosa, MG, Brazil \\ 3 Universidade Federal Rural da Amazônia, Av. Presidente Tancredo Neves 2501, CEP 66077-830, Belém, PA, Brazil \\ ${ }_{4}^{4}$ Universidade Federal do Ceará, Av. da Universidade 2853, CEP 60020181, Fortaleza, CE, Brazil \\ * Corresponding author: saulofabricioagro@gmail.com; (D) https://orcid.org/0000-0002-0694-1798
}

\begin{abstract}
This study aimed to evaluate and select progenies and matrices of cupuassu-tree siblings, and to select Brazilian mahogany matrices with superior characteristics to be used in agroforestry systems (AFS). Twenty-five full cupuassu tree sibling progenies and one Brazilian mahogany half-sibling progeny were evaluated. The study was conducted for 14 years in a commercial property in Tomé Açu, Pará State, Brazil. The number of fruits and fruit yield per plant, as well as the rate of plants with symptoms of witches' broom disease, were used as response variables for cupuassu. For mahogany, the following response variables were used: total height, commercial height, crown height, diameter at breast height and commercial wood volume. There were five cupuassu tree progenies with interesting characteristics to be used in AFS. Based on the high values observed in the selection accuracy and heritabilities, a good potential for the selection of promising individuals in the cupuassu tree population is inferred. Based on the ranking of genotypic values and their agronomic performance, 10 matrices of cupuassu tree were selected. For Brazilian mahogany, three matrices showed excellent silvicultural performance. The matrices of these two species should be propagated vegetatively in order to evaluate clonal tests.
\end{abstract}

KEYWORDS: Theobroma grandiflorum, Swietenia macrophylla, genetic breeding, intercropping

\section{Seleção simultânea de genótipos de cupuaçuzeiro e mogno brasileiro, em um sistema agroflorestal no Pará, Brasil}

\section{RESUMO}

Este trabalho teve por objetivo avaliar e selecionar progênies e matrizes de irmãos completos de cupuaçuzeiro e, simultaneamente, selecionar matrizes de mogno brasileiro com características superiores, para utilização em sistemas agroflorestais (SAFs). Foram avaliadas 25 progênies de irmãos completos de cupuaçuzeiro e uma progênie de meio irmão de mogno brasileiro. O estudo foi conduzido por 14 anos em uma propriedade comercial em Tomé Açu, Pará. Para o cupuaçuzeiro, foram utilizadas como variáveis de resposta o número e a produção de frutos por planta, e a taxa de plantas com sintomas da doença vassoura-debruxa. Para o mogno, empregou-se a altura total, altura comercial, altura da copa, DAP e volume de madeira comercial. Os resultados revelaram cinco progênies de cupuaçuzeiro com características interessantes para emprego em SAFs. Com base nos altos valores observados na acurácia de seleção e herdabilidade, inferimos um bom potencial de seleção de indivíduos promissores na população de cupuaçuzeiro. Dez matrizes de cupuaçuzeiro foram selecionadas com base no ranqueamento dos valores genotípicos e desempenho agronômico. Para o mogno brasileiro, três matrizes apresentaram ótimo desempenho silvicultural. As matrizes destas duas espécies deverão ser propagadas vegetativamente, para avaliaçấo em ensaios clonais.

PALAVRAS-CHAVE: Theobroma grandiflorum, Swietenia macrophylla, melhoramento genético, consórcio 


\section{INTRODUCTION}

Agroforestry systems (AFS) are multifunctional systems that can provide a wide range of economic, sociocultural, and environmental benefits related to simultaneous or sequential interaction between agronomic crops and forest species. The benefits include carbon sequestration (Lorenz and Lal 2014), decreased erosion (Liu et al. 2016), restoration of the local ecosystem (Poch and Simonetti 2013) and conservation of water resources (Pavlidis and Tsihrintiz 2018). These systems have a high level of sustainability and benefit the producers by increasing food security and financial returns, which are diversified and scaled throughout the growing season (Armengot et al. 2016). In the Amazon region, AFSs are often present on small properties in the form of agroforestry yards, a kind of subsistence system that mainly assures the food security of the producer's family (Florentino et al. 2007; Castro et al. 2009). In order to achieve a more sustainable cultivation environment, AFSs were improved for commercialscale production, aiming at a competitive alternative to less sustainable cultivation models, such as monoculture systems and slash-and-burn agriculture (Alfaia et al. 2004; Utomo et al. 2016).

The cupuassu tree, Theobroma grandiflorum (Willd. ex Spreng.) Schum. (Malvaceae) is a perennial fruit species native to the Brazilian Amazon. Its fruit pulp is used in the food industry (Pugliese et al. 2013) and its almonds can be used in the pharmaceutical and cosmetics industries, as well as in the production of a chocolate-like product named cupulate (Gonçalves et al. 2010). The species is the target of a breeding program that aims to obtain individuals with high yield and tolerance to Moniliophthora perniciosa (Stahel) Aime $\&$ Philips-Mora fungus, an etiological agent of the witches' broom disease (Alves et al. 2009). It is of great importance to select individuals adapted to AFS cultivation conditions, as most family farmers cultivate cupuassu tree.

Brazilian mahogany, Swietenia macrophylla King. (Meliaceae) is a tree species native to the Amazon region and greatly valued for its high quality wood (Degen et al. 2013). For this reason, in 2002, Brazilian mahogany was added to Appendix II of the Convention on International Trade of Wild Flora and Fauna Species Endangered of Extinction (CITES) (Grogan and Loveless 2013). Nevertheless, illegal logging in natural populations are known to still occur. Thus, there is a need for initiatives aimed at the genetic conservation of Brazilian mahogany. The selection of genotypes with superior characteristics can result in future mahogany cultivars for planting, mainly in AFSs, thus reducing anthropic pressure on remaining wild stands.

Genetic breeding must take into account the interests of the producers, namely high productive capacity, resistance to pests and diseases, and acceptable adaptability and stability characteristics (Maia et al. 2011). Using the same cultivation conditions under which genotypes will be submitted by producers, such as the proposed conditions for the evaluation of progenies in AFS, allows the possibility of the indirect selection of more adapted individuals. Based on this hypothesis, this study aimed to evaluate cupuassutree full sibling progenies by selecting the most promising individuals for cloning and to evaluate and select Brazilian mahogany matrices with superior silvicultural characteristics for later use in AFS.

\section{MATERIAL AND METHODS}

The experiment was carried out for 14 years (2005-2019), in a rural producer area located in the Tomé Açu municipality, northeastern Pará state $\left(02^{\circ} 26^{\prime} 03.0^{\prime \prime} S, 48^{\circ} 18^{\prime} 37.6^{\prime \prime} \mathrm{W}\right)$, $120 \mathrm{~km}$ from the state capital, Belém. The municipality is pioneering in the use of commercial AFS in the Amazon region, involving mainly timber and fruit species, due to the influence of an agricultural cooperative created by the Japanese-Brazilian colony that settled in the region, which processes and distributes the products from these systems (Barros et al. 2009).

The experimental area occupies approximately 1 ha and has a 30-year history of continuous use. It was primarily dedicated to the cultivation of black pepper, Piper nigrum L., followed by intercropping between sweet pepper, Capsicum chinense Jacq., papaya, Carica papaya L. and pumpkin, Curcubita sp. L. In the last 14 years, the area has been destined to the agroforestry system reported in this study. The area is bordered by a commercial cacao, Theobroma cacao L. plantation combined with açaí, Euterpe oleraceae Mart. on one side, and by a 15-year old secondary forest on the other.

According to the Köppen classification, the climate of the region is Ami (Bolfe and Batistella 2012), with $2,716 \mathrm{~mm}$ average annual precipitation, $85 \%$ average relative humidity, and $26.4^{\circ} \mathrm{C}$ average temperature. There is a high-rainfall period from December to May, and a drier period from June to November (Figure 1). Climatic data were collected from the meteorological station of Tomé Açu. The soil of the experimental area is classified as Yellow Latosol (EMBRAPA

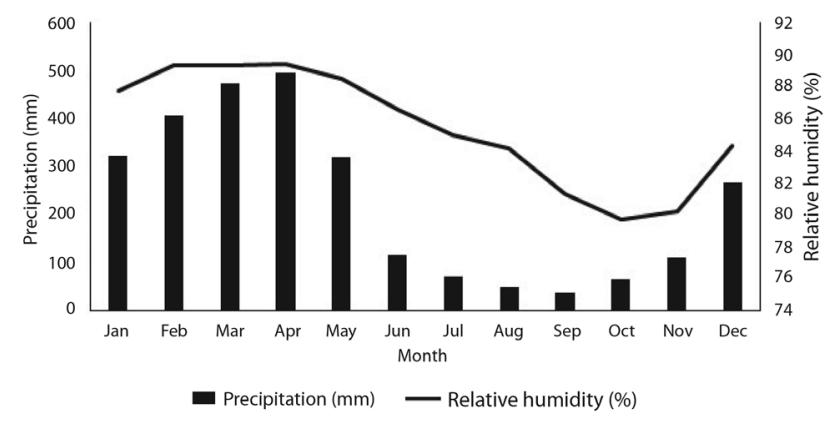

Figure 1. Average monthly precipitation $(\mathrm{mm})$ and average relative humidity (\%) for the 14 years (2005-2019) of experiment in the municipality of Tomé Açu, Pará state, Brazil. 
2016), with coarse texture, deep, high acidity, low natural fertility and absence of waterproofing layers, as well as light compaction attributed to the passage of mowing machines (twice a year).

The AFS under study was initially composed of three species: cupuassu tree, passion fruit, Passiflora edulis Sims, and Brazilian mahogany. All species were planted in March 2005, after mechanical cleaning of the area and preparation of individualized holes, applying $150 \mathrm{~g}$ of natural phosphate to each hole.

Twenty-five full cupuassu-tree sibling progenies (Table 1) from the breeding program of Embrapa Amazônia Oriental were evaluated in a randomized block design with five replicates and three plants per plot, which were planted at $5 \times 5$-m spacing. As for the progeny parents under study, genotypes already released as commercial cultivars, such as BRS Codajás (186), BRS Manacapuru (215), BRS Coari (174) and BRS Belém (286), as well as other pre-selected genotypes with great yield and/or tolerance to M. perniciosa, were used. Passion fruit planted between cupuassu-tree rows at a $5 \times 2.5-\mathrm{m}$ spacing provided temporary shading to cupuassu trees during the first four years of planting.

Brazilian mahogany seedlings came from open pollinated seeds planted at $20 \times 10-\mathrm{m}$ spacing with a density of 50 trees per hectare. This species provided the definitive shading to cupuassu trees until the end of the experimental period. The density of the AFS system is 1,250 plants per hectare.

Data collection of cupuassu-tree production began two years after planting and lasted until 2018/2019, totalizing 11 harvests. In each harvest, the number of fruits per plant and the average weight of five fruits per plant and crop were recorded. Thus, it was possible to estimate the fruit yield per plant in kilograms for each crop [Yield $(\mathrm{kg})=$ number of fruits $\mathrm{x}$ average weight of fruits]. For each progeny, the rate of occurrence of plants with $M$. perniciosa symptoms was estimated by the coefficient between the number of plants with symptoms of the disease and the number of healthy plants.

The selection of progenies was carried out using the mixed model methodology (REML/BLUP), using SELEGEN software (Resende 2016). Simultaneously, the variance components and genetic parameters (REML method) were estimated, and the genotypic values were predicted (BLUP method). The estimated genetic parameters were genotypic variance, variance between plots, variance within plots and phenotypic variance. We also considered the plot-effects coefficient of determination, selection accuracy, heritability within the plot, heritability adjusted for the progeny mean, and restricted sense heritability. The statistical model used was:

$$
y=X r+Z g+W p+e
$$

where $y$ is the data vector, $r$ is the vector of the repetition effects (assumed to be fixed) added to the general mean, $g$ is the vector of the individual genotypic effects (assumed to be random), $p$ is the vector of plot effects (assumed to be random), $e$ is the vector of errors or residuals (random), and capital letters represent the incidence matrices for the referred effects (Resende 2007).

The 10 progenies that ranked highest in production variables and a maximum of $40 \%$ of plants affected by witches' broom symptoms were selected. After plants were ranked in descending order of their genotypic values for number of fruits and fruit yield per plant, matrices that should effectively be selected and cloned were identified in the selected progenies. This selection took into account the following criteria: selection of two ortets per progeny, in order to avoid the genetic variability restriction between selected genotypes, and ortets that were asymptomatic for $M$. perniciosa.

For Brazilian mahogany, 48 trees from open pollinated seeds were evaluated. Evaluations consisted of measuring total height (ht) (m), commercial height (hcom) (m), crown height (hcop) (m), diameter at breast height (DBH) $(\mathrm{cm})$ and commercial wood volume $\left(\mathrm{m}^{3}\right)$. Heights were initially determined with a metric scale and later with a VERTEX IV digital hypsometer. DBH was determined using a measuring tape by measuring the circumference at breast height (CAP). The formula $\mathrm{CAP} / \pi$ converted the values.

The estimated commercial volume was estimated using the equation proposed by Fernandes et al. (2017):

Commercial wood volume $=-9.38450+2.06586 *$ $\ln (D B H)+0.72929+\ln ($ hcom $)$

When selecting a matrix, its total height should be composed mostly of commercial height, DBH values should be high, and commercial wood volume should attain market value (Beltrame et al. 2012). Therefore, for the selection of promising matrices of Brazilian mahogany, the five estimator variables were taken into account, especially the volume of commercial wood. The mass selection method was adopted, with the cutoff point established as one standard deviation above the average of each variable.

\section{RESULTS}

The number of cupuassu fruits produced during the eleven harvests ranged from 1 to 18 (Figure 2). Production in the first three harvests was low, with an increasing tendency over the years and an alternation of production peaks. From the seventh harvest onwards, although the previously observed fluctuation between harvests occurred again, it was possible to notice a tendency towards stability. The tenth crop reached the highest production peak in the series, with an average of more than $30 \mathrm{~kg}$ fruit per plant per crop. Considering a stand of 400 plants ha $^{-1}$, the yield would be around 12 tons fruit ha ${ }^{-1}$, exceeding the estimated yield for the 'BRS Carimbó' cultivar, 
which is currently marketed, demonstrating the potentiality of the studied progenies.

Throughout the 11 harvests, the average number of fruits per plant was 12, with a yield of $17 \mathrm{~kg}$ per plant per harvest (Table 1). Regarding both number of fruits and fruit yield, nine progenies $(5,6,11,23,36,37,43,49$ and 52) stood out. There was no agreement on one only progeny in the 10

Table 1. Progeny ancestry, phenotypic value and genetic value of progenies for number of fruits per plant and harvest ( $\mathrm{N}$ fruits), and fruit yield (kg per plant and harvest), and proportion of plants with witch's broom disease (Moniliophthora perniciosa) symptoms of 25 cupuassu tree (Theobroma grandiflorum) progenies evaluated during 11 harvests in an experimental agroforestry system in the municipality of Tomé Açu, Pará state, Brazil. Values in bold indicate progenies ranked highest for both production variables according to BLUP.

\begin{tabular}{|c|c|c|c|c|c|c|}
\hline \multirow[b]{2}{*}{ Progeny } & \multirow[b]{2}{*}{ Ancestry } & \multicolumn{2}{|c|}{$N$ fruits } & \multicolumn{2}{|c|}{ Fruit yield } & \multirow{2}{*}{$\begin{array}{c}\text { Plants } \\
\text { affected by } \\
\text { M. perniciosa } \\
\text { (\%) }\end{array}$} \\
\hline & & $\begin{array}{c}\text { Phenotypic } \\
\text { value }\end{array}$ & $\begin{array}{l}\text { Genetic } \\
\text { value }\end{array}$ & $\begin{array}{c}\text { Phenotypic } \\
\text { value }\end{array}$ & $\begin{array}{l}\text { Genetic } \\
\text { value }\end{array}$ & \\
\hline 1 & 186 × 286 & 9.4 & 9.8 & 12.7 & 13.7 & 53 \\
\hline 4 & 174 x Sekó & 12.6 & 12.5 & 15.9 & 16.0 & 47 \\
\hline 5 & 186 x 184 & 14.5 & 14.1 & 20.7 & 19.9 & 20 \\
\hline 6 & $174 \times 184$ & 13.2 & 12.9 & 21.2 & 20.2 & 58 \\
\hline 8 & 186 x Parau & 10.7 & 10.9 & 16.8 & 16.7 & 20 \\
\hline 9 & $215 \times 220$ & 11.0 & 11.1 & 16.5 & 16.6 & 47 \\
\hline 11 & $220 \times 286$ & 14.3 & 14.0 & 19.5 & 19.0 & 27 \\
\hline 13 & 1074 x Parau & 9.0 & 9.3 & 16.0 & 16.1 & 100 \\
\hline 17 & $174 \times 220$ & 9.8 & 10.1 & 11.4 & 12.3 & 60 \\
\hline 19 & $174 \times 286$ & 11.4 & 11.4 & 14.9 & 15.2 & 20 \\
\hline 20 & $186 \times 1074$ & 9.5 & 9.8 & 14.8 & 15.2 & 53 \\
\hline 21 & $186 \times 215$ & 105 & 10.7 & 15.7 & 15.9 & 20 \\
\hline 22 & $174 \times 1074$ & 9.4 & 9.7 & 16.4 & 16.4 & 53 \\
\hline 23 & 215 x Sekó & 15.3 & 14.8 & 23.1 & 21.9 & 33 \\
\hline 25 & $215 \times 286$ & 10.8 & 10.8 & 14.2 & 14.6 & 60 \\
\hline 28 & $174 \times 186$ & 6.6 & 7.4 & 9.7 & 11.1 & 20 \\
\hline 29 & $173 \times 186$ & 8.4 & 8.8 & 11.8 & 12.8 & 40 \\
\hline 30 & 220 x Parau & 10.0 & 10.2 & 15.2 & 15.5 & 60 \\
\hline 36 & 174 x M45 & 17.0 & 16.3 & 22.7 & 21.7 & 60 \\
\hline 37 & 186 x M138 & 15.8 & 15.2 & 18.0 & 17.8 & 40 \\
\hline 38 & $215 \times 554$ & 9.9 & 10.1 & 13.8 & 14.4 & 67 \\
\hline 40 & $174 \times 554$ & 8.1 & 8.5 & 11.5 & 12.4 & 40 \\
\hline 43 & $220 \times 12$ & 13.9 & 13.6 & 20.2 & 19.5 & 100 \\
\hline 49 & 174x Hans 1 & 14.5 & 14.0 & 20.4 & 19.6 & 47 \\
\hline 52 & $174 \times 217$ & 13.6 & 13.4 & 20.0 & 19.4 & 40 \\
\hline \multicolumn{2}{|c|}{ Média } & 11.6 & 11.6 & 16.5 & 16.5 & 47 \\
\hline \multicolumn{2}{|r|}{ C.V. } & \multicolumn{2}{|c|}{$19.9 \%$} & \multicolumn{2}{|c|}{$23.8 \%$} & $46.3 \%$ \\
\hline
\end{tabular}

highest ranked. Progeny 4 ranked highest for number of fruits per plant, while progeny 8 ranked highest for fruit production (kg per plant).

Almost half of the plants showed some manifestation of witches' broom disease, and no progeny had $100 \%$ of plants free from it. The high coefficient of variation indicated that progeny behavior was quite variable (Table 1). There was great variation between the nine most productive progenies regarding the incidence of $M$. perniciosa. The least affected progenies were $5(20 \%), 11(27 \%)$ and $23(33 \%)$. In the first, only the female parent was resistant, while in the other two, both parents were resistant (Table 1). It is noteworthy that progeny 23 ( 215 x Sekó) has in the Sekó parent a source of resistance that probably differs from the resistance genes currently used in the breeding program. Progenies 52 and 37 showed a regular tolerance $(40 \%)$. The progenies most sensitive to the disease were 43 (100\%), 36 (60\%), 6 (58\%) and 49 (47\%). In the first, both parents were susceptible and all plants of this progeny showed some symptom of the disease. The other three progenies had only one susceptible parent.

Although not showing the same productivity as the nine progenies mentioned, progenies 19, 21 and 28 stood out regarding resistance to $M$. perniciosa. They are primary hybrids among cultivars released in 2002: BRS Coari (174), BRS Codajás (186), BRS Manacapuru (215) and Belém (286). These progenies should participate in the resistance gene pyramidation process of the cupuassu breeding program developed at Embrapa Amazônia Oriental.

New sources of productivity genes were identified in progenies 8, 36, 37 and 49, which include Parauapebas, M45, M138 and Hans1 as male parental clones. Clone Hans 1 , which is a genotype that does not produce seeds, was collected in Cametá (Pará state), from a tree that had half of the crown producing seeded fruits and the other producing seedless fruits.

The estimated genetic parameters indicated a good potential for selecting individuals from the population (Table

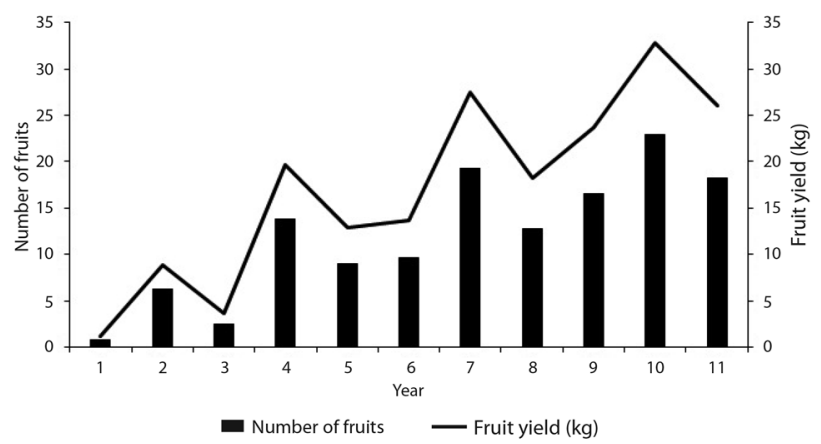

Figure 2. Average number of fruits and fruit yield (kg per plant) of cupuassu tree (Theobroma grandiflorum) per year during 11 years in an experimental agroforestry system in consortium with Brazilian mahogany (Swietenia macrophyla) progenies and passion fruit (Passiflora edulis) in the municipality ofTomé Açu, Pará state, Brazil. 
2), as shown by the high genotypic variance values of 6.43 and 11.09 , related to the number of fruits and fruit yield, respectively. The accuracy of the selection was higher than $90 \%$ in both variables. The low coefficient of determination for plot effect, and the low variance between plots, indicate that experimental conditions were similar among progenies. The high heritability values for both production traits (Table 2) indicates that genotype selection will be effective. Fruit yield, being a polygenic character dependent on the number of fruits and fruit weight, is more susceptible to environmental influence. For this reason, it presented lower values of heritability.

Genotypic values allowed the identification of the 10 most promising matrices within the five preselected progenies (Table 3). For each progeny, two matrices with the highest genotypic values were chosen for propagation by grafting and clone production, or use in a clonal seed orchard. The use of these materials is estimated to provide an average gain of $32 \%$ for number of fruits per plant and $44 \%$ for fruit production (kg per plant). The new estimated average for the improved clonal population is 19.7 fruits per plant, corresponding to $25.9 \mathrm{~kg}$ per plant. With a density of 400 plants per ha, fruit production is expected to reach 10 tons ha ${ }^{-1}$.

Mahogany trees showed high variability in the analyzed traits, which could be used for selection. Divergences close to $100 \%$ were observed for height and DBH (Table 4). For the most economically relevant variable, commercial wood volume, the amplitude was greater than $400 \%$ (Table 4). These data reinforce the premise that some genotypes had

Table 2. Overall average values (mean $\pm S D$ ), average values of selected individuals (mean \pm SD) and estimation of genetic parameters for production variables (number of fruits per plant and fruit yield) of 25 cupuassu tree (Theobroma grandiflorum) progenies evaluated during 11 harvests in an experimental agroforestry system in the municipality of Tomé Açu, Pará state, Brazil.

\begin{tabular}{lcc}
\hline Genetic parameter & N fruits/plant & $\begin{array}{c}\text { Fruit yield } \\
\text { (kg/plant) }\end{array}$ \\
\hline Overall average & $11.96 \pm 2.83$ & $16.92 \pm 3.85$ \\
\hline Selected individuals average & $20.20 \pm 5.87$ & $29.90 \pm 5.67$ \\
Genotypic variance & 6.43 & 11.09 \\
\hline Between plots variance & 0.04 & 0.06 \\
Within plots variance & 13.2 & 34.34 \\
Phenotypic variance & 19.68 & 45.5 \\
$\begin{array}{l}\text { Plot effects coefficient of } \\
\text { determination }\end{array}$ & 0.002 & 0.001 \\
\hline $\begin{array}{l}\text { Selection accuracy } \\
\text { Adjusted heritability for the progeny } \\
\text { mean }\end{array}$ & 0.93 & 0.9 \\
\hline $\begin{array}{l}\text { Additive heritability within the plot } \\
\text { Restricted sense heritability }\end{array}$ & 0.48 & 0.82 \\
\hline
\end{tabular}

Table 3. Cupuassu tree genotypes (Theobroma grandiflorum) selected for clona propagation during 11 harvests in an experimental agroforestry system in Tomé Açu (Pará state, Brazil) with 25 progenies. Values are presented for genotypic value genetic gain and new mean for number of fruits per plant and harvest, and fruit yield (kg per plant and harvest)

\begin{tabular}{|c|c|c|c|c|c|c|}
\hline \multirow[b]{2}{*}{ Genotype } & \multicolumn{3}{|c|}{$\mathrm{N}$ fruits/plant } & \multicolumn{3}{|c|}{ Fruits yield (kg/plant) } \\
\hline & $\begin{array}{c}\text { Genotypic } \\
\text { value }\end{array}$ & $\begin{array}{c}\text { Genetic } \\
\text { gain }\end{array}$ & $\begin{array}{l}\text { New } \\
\text { mean }\end{array}$ & $\begin{array}{l}\text { Genotypic } \\
\text { value }\end{array}$ & $\begin{array}{c}\text { Genetic } \\
\text { gain }\end{array}$ & $\begin{array}{l}\text { New } \\
\text { mean }\end{array}$ \\
\hline 52.3 .1 & 22.9 & 12.3 & 23.9 & 29.7 & 13.2 & 29.7 \\
\hline 23.3 .1 & 16.0 & 6.4 & 18.0 & 28.4 & 12.5 & 29.0 \\
\hline 23.3 .2 & 15.3 & 5.7 & 17.2 & 26.1 & 10.6 & 27.1 \\
\hline 11.4 .2 & 19.4 & 9.8 & 21.4 & 24.2 & 9.8 & 26.4 \\
\hline 5.1 .3 & 14.2 & 4.8 & 16.4 & 23.8 & 9.5 & 26.1 \\
\hline 37.1 .1 & 22.0 & 11.7 & 23.3 & 22.6 & 8.7 & 25.2 \\
\hline 52.2 .2 & 14.1 & 4.7 & 16.3 & 22.4 & 8.1 & 24.6 \\
\hline 5.3 .1 & 16.5 & 7.0 & 18.5 & 21.8 & 7.6 & 24.2 \\
\hline 37.2 .1 & 24.8 & 13.3 & 24.8 & 21.1 & 6.8 & 23.4 \\
\hline 11.4 .3 & 15.3 & 5.8 & 17.4 & 21.0 & 6.8 & 23.3 \\
\hline
\end{tabular}

Coding of individuals $x . y . z$, where $x=$ progeny, $y=$ location block, and $z=$ plant.

Table 4. Silvicultural performance of 48 Brazilian mahogany (Swietenia macrophyla) matrices for total tree height (m), commercial height (m), canopy height $(\mathrm{m})$; diameter at breast height - $\mathrm{DBH}(\mathrm{cm})$ and estimated commercial volume $\left(\mathrm{m}^{3}\right)$ in the $14^{\text {th }}$ year in an experimental agroforestry system in the municipality of Tomé Açu, Pará state (Brazil). Bold values indicate individuals above the cutoff point.

\begin{tabular}{|c|c|c|c|c|c|}
\hline Matrices & $\begin{array}{c}\text { Total } \\
\text { height (m) }\end{array}$ & $\begin{array}{l}\text { Commercial } \\
\text { height (m) }\end{array}$ & $\begin{array}{c}\text { Canopy } \\
\text { height (m) }\end{array}$ & $\begin{array}{l}\mathrm{DBH} \\
(\mathrm{cm})\end{array}$ & $\begin{array}{c}\text { Estimated } \\
\text { commercial } \\
\text { volume }\left(\mathrm{m}^{3}\right)\end{array}$ \\
\hline 1 & 14.7 & 3.4 & 11.3 & 26.4 & 0.178 \\
\hline 2 & 14.6 & 5.1 & 9.5 & 29.9 & 0.309 \\
\hline 3 & 16.1 & 5.9 & 10.2 & 30.3 & 0.351 \\
\hline 4 & 15.4 & 4.2 & 11.2 & 35.7 & 0.385 \\
\hline 5 & 11.7 & 4.2 & 7.5 & 21.7 & 0.137 \\
\hline 6 & 12.2 & 4.4 & 7.8 & 29.0 & 0.260 \\
\hline 7 & 16.6 & 5.2 & 11.4 & 36.9 & 0.484 \\
\hline 9 & 16.3 & 3.7 & 12.6 & 37.6 & 0.391 \\
\hline 12 & 17.6 & 4.7 & 12.9 & 39.5 & 0.516 \\
\hline 13 & 15.1 & 5.9 & 9.2 & 27.4 & 0.286 \\
\hline 14 & 15.0 & 4.2 & 10.8 & 29.6 & 0.262 \\
\hline 15 & 15.5 & 3.8 & 11.7 & 31.9 & 0.283 \\
\hline 16 & 12.4 & 5.4 & 7.0 & 35.7 & 0.463 \\
\hline 17 & 16.9 & 3.6 & 13.3 & 33.8 & 0.307 \\
\hline 18 & 18.1 & 4.2 & 13.9 & 38.2 & 0.444 \\
\hline 19 & 15.9 & 4.1 & 11.8 & 33.1 & 0.325 \\
\hline
\end{tabular}


Table 4. Continued.

\begin{tabular}{|c|c|c|c|c|c|}
\hline Matrices & $\begin{array}{c}\text { Total } \\
\text { height (m) }\end{array}$ & $\begin{array}{l}\text { Commercial } \\
\text { height (m) }\end{array}$ & $\begin{array}{c}\text { Canopy } \\
\text { height (m) }\end{array}$ & $\begin{array}{l}\mathrm{DBH} \\
(\mathrm{cm})\end{array}$ & $\begin{array}{c}\text { Estimated } \\
\text { commercial } \\
\text { volume }\left(\mathrm{m}^{3}\right)\end{array}$ \\
\hline 20 & 14.4 & 4.4 & 10.0 & 23.6 & 0.169 \\
\hline 21 & 15.9 & 4.6 & 11.3 & 28.3 & 0.256 \\
\hline 22 & 16.3 & 4.5 & 11.8 & 27.7 & 0.240 \\
\hline 24 & 16.5 & 5.2 & 11.3 & 33.8 & 0.402 \\
\hline 25 & 16.1 & 4.5 & 11.6 & 37.3 & 0.443 \\
\hline 27 & 11.3 & 3.0 & 8.3 & 35.7 & 0.301 \\
\hline 28 & 16.0 & 3.8 & 12.2 & 35.4 & 0.352 \\
\hline 29 & 13.8 & 5.8 & 8.0 & 30.3 & 0.347 \\
\hline 30 & 15.0 & 4.0 & 11.0 & 28.3 & 0.231 \\
\hline 32 & 18.7 & 5.2 & 13.5 & 31.5 & 0.349 \\
\hline 34 & 15.5 & 4.6 & 10.9 & 30.9 & 0.306 \\
\hline 35 & 19.4 & 4.7 & 14.7 & 32.5 & 0.345 \\
\hline 37 & 17.5 & 4.6 & 12.9 & 32.8 & 0.346 \\
\hline 38 & 13.6 & 4.4 & 9.2 & 32.8 & 0.335 \\
\hline 39 & 14.9 & 3.7 & 11.2 & 26.1 & 0.184 \\
\hline 40 & 14.9 & 5.8 & 9.1 & 24.8 & 0.231 \\
\hline 43 & 13.1 & 4.9 & 8.2 & 33.8 & 0.385 \\
\hline 44 & 15.9 & 5.1 & 10.8 & 32.2 & 0.358 \\
\hline 45 & 15.5 & 6.4 & 9.1 & 30.3 & 0.373 \\
\hline 46 & 14.8 & 6.2 & 8.6 & 30.9 & 0.380 \\
\hline 47 & 17.8 & 4.9 & 12.9 & 41.7 & 0.596 \\
\hline 48 & 16.8 & 4.7 & 12.1 & 28.7 & 0.266 \\
\hline $\begin{array}{l}\text { Maxi- } \\
\text { mum }\end{array}$ & 19.4 & 6.4 & 14.7 & 41.7 & 0.596 \\
\hline $\begin{array}{l}\text { Mini- } \\
\text { mum }\end{array}$ & 11.3 & 3.0 & 7.0 & 21.7 & 0.137 \\
\hline Mean & 15.5 & 4.7 & 10.8 & 31.7 & 0.331 \\
\hline SD & 1.8 & 0.8 & 1.9 & 4.5 & 0.098 \\
\hline $\begin{array}{l}\text { Cutoff } \\
\text { point }\end{array}$ & 17.3 & 5.5 & 12.7 & 36.2 & 0.429 \\
\hline
\end{tabular}

early vegetative development and deserved to be identified and selected.

Considering the established cutoff point for each variable, the mass selection applied to the 48 analyzed trees revealed six matrices suitable for selection $(7,12,16,18,25,47)$, which had commercial wood volume above $0.43 \mathrm{~m}^{3}, 48.8 \%$ higher than the average of all plants (Table 4). Of these matrices, if only the trees that had the highest growth in height in the first years (12 and 47) were selected, the difference would increase to $68.5 \%$. Among these six matrices, three $(12,18$ and 47) would be identified solely by total height, none by commercial height, two (12 and 18) by crown height, and the majority $(7,12,18,25$ and 47$)(83 \%)$ by DBH. These results highlight the decisive importance of $\mathrm{DBH}$ in the evaluation of Brazilian mahogany trees. Moreover, among all evaluated variables, $\mathrm{DBH}$ is the easiest to measure in the field.

Considering exclusively the biological aspect of AFSs, mahogany plants with greatest height increments should be identified. Matrices 12, 18, 32, 35, 37 and 47 had the best performances for total height, as these trees allow more light into the system.

Thus, considering all variables, matrices 12, 18 and 47 were the most promising regarding economic return and, therefore, should be selected. These three matrices presented all the silvicultural characteristics that an Brazilian mahogany plant must have, such as high stem development, high DBH and good wood production.

Mahogany survival rate was $80 \%$, indicating good adaptability of the plants to the cropping system. Tip attacks by the Hypsipyla grandella Zeller pest were not quantified. However, trees damaged by the pest could be observed, especially in the early years. This damage caused reduction in the commercial height of the stem in the attacked plants.

\section{DISCUSSION}

The choice of species that compose AFS should be made with care, recommending plants that explore different strata both above and below ground, in order to ensure beneficial interactions among individuals (Tonini and Arco-Verde 2005; Condé et al. 2013). In the present study, the selected species were planted simultaneously, however, due to its rapid growth, Brazilian mahogany stood out, occupying the upper stratum of the AFS with full use of sunlight. Drobyshev et al. (2007) observed faster growth of Brazilian mahogany plants with canopy fully exposed to the sun when compared with plants under shade conditions. Under natural conditions, juvenile Brazilian mahogany individuals are able to withstand suppression caused by the upper stratum crown and react significantly when exposed to sunlight (Grogan et al. 2005). However, occupying different strata does not nullify competition among species, and it is important to quantify possible losses caused by interspecific competition (Alves et al. 2018).

The irregular behavior of cupuassu fruit production over time was owed to insufficient water supplementation, probably due to insufficient irrigation management in the area, failing to compensate the water deficit in the critical months of the year, especially in years with little rainfall in the second semester, when flowering occurs and fruiting begins, reflecting on the production of the subsequent harvest. Stressed plants tend to abort small flowers and fruits and, if heavy rainfall occurs 
after a drought period, it can cause cracks in developing fruits (Venturieri 2011).

Differentiated responses of cupuassu tree genotypes to $M$. perniciosa might be due to the heterozygous state of gene loci responsible for the expression of disease resistance (Alves et al. 2009). Pathogens and hosts coevolve allowed the emergence of different types of specialization to overcome the resistance of plants (Futuyma 2009). Therefore, the possibility of resistance breakdown increases as pathogen variability increases, especially for varieties that contain few vertical resistance genes (Tschurtschenthaler et al. 2012). In this context, the addition of genes of diffreent origin to the genotypes identified as asymptomatic and potentially resistant to witches' broom in our study should be important to assure that new progenies are more resistant to new fungal strains.

Motamayor et al. (2008) highlighted the need to explore heterosis arising from the crossing between individuals of different genetic groups. In cupuassu tree, the vegetative propagation of genetically superior matrices identified by their productive performance allows the full use of heterosis (Regazzi et al. 2002). Therefore, studies on preliminary compatibility and grouping should be performed in the initial crossings, such as those performed by Santos et al. (2015).

The observed selection accuracy values (Table 2) are classified as very high (>0.9) by Resende and Duarte (2007), attesting the reliability of the data and selection efficiency. The low coefficients of determination values (Table 2) enable us to infer that the experimental conditions used in the present study were adequate. Alves and Resende (2008) also found low coefficients of determination and stated that low magnitudes of these parameters indicate good environmental control. The heritability values found here were relatively high, considering both quantitative characteristics, which theoretically causes high residual dispersion (Maia et al. 2011). Other studies estimated heritability in restricted sense of 0.55 (Souza et al. 2002) and 0.48 (Alves and Resende 2008) for number of fruits for four harvests, and values close to 0.69 for number of fruits and 0.67 for fruit yield $(\mathrm{kg})$ for seven harvests (Souza et al. 2002), indicating that increasing the number of evaluations improves the accuracy of the heritability estimate.

The genetic gain observed in our study was similar to that obtained by Alves and Resende (2008), who found values close to $33 \%$ for number of fruits. However, this comparison is only referential, because the parameter is a function of the average initial population and the selection pressure. Alves et al. (2010) estimated $82 \%$ gain for fruit production, which is a value higher than that found in the present study. However, the authors worked with a lower selection index and lower initial average. Other factors, such as progeny similarity and high number of replicates, which allows reduction of the environmental effect, can significantly influence the estimation of genetic parameters (Araújo et al.,
2014). The genetic gains with clonal propagation are higher in comparison to sexual propagation due to the increase of the dominant effects (Matheson and Lindgren, 1985). The selection of individuals for cloning in the present study aimed to capitalize on all the genetic gain to constitute a high performance population (Alves and Resende 2008).

Souza et al. (2002) also highlighted the need to consider at least four harvests in the evaluation to demonstrate the temporal stability of materials. We evaluated almost three times the minimum number of harvests, in order to optimize the selection accuracy. This allowed the selection of progenies and matrices that, combined with good fruit production, should allow production to be staggered during the agricultural year, extending of the harvest period and increasing financial returns for farmers.

Regarding Brazilian mahogany, a steady and satisfactory growth was observed, showing a good adaptation by the plant to the cropping system. The mortality was owed to difficulties in establishing seedlings in the field, as well as other factors inherent to intercropping in agroforestry systems, such as interspecific competition, especially for water and nutrients (Giustina et al. 2017). These factors are of common occurrence and considered a natural condition of the species (Grogan and Landis 2009). Another important factor for the diminished mortality rate was the low incidence of $H$. grandella attack, which can be attributed to the species diversification provided by the agroforestry system. Wallau et al. (2008) related the failure of Brazilian mahogany monocultures to reduce the incidence of $H$. grandella. Monoculture conditions give the pest a homogeneous distribution and abundance of food, causing damage to the stem, which results in lower commercial height and, consequently, lower wood production (Togni et al. 2009). The vegetation diversity provided by AFSs favors the proliferation of natural enemies of agricultural pests, and the lower density of the species decreases the availability of food to the pest (Silva et al. 2011), a viable alternative to cultural pest control. In our study, the use of three species and the proximity of the experimental area to native vegetation likely contributed to lower pest incidence.

\section{CONCLUSIONS}

For presenting good yields and/or low rates of plants affected by $M$. perniciosa symptoms, cupuassu tree progenies $5,11,23,37$ and 52 should be recommended to growers for small-scale planting. Of these progenies, 10 individuals were identified and will be submitted to clonal evaluations in different environments before being recommended to producers. The Brazilian mahogany matrices 12, 18 and 47, which presented adequate silvicultural characteristics, should be propagated for reassessment in the clonal form in agroforestry systems in the Amazon region. 


\section{ACKNOWLEDGMENTS}

The authors would like to thank Mr. Paulino Mikio Taguchi, Tokumaru Farm's owner, where this experiment was conducted, and the field workers José Raimundo Quadros Fernandes, José Oliveira de Aviz and Antonio Fontel Miranda Pinheiro, for the continuous help throughout the experimental years.

\section{REFERENCES}

Alfaia, S.S.; Ribeiro, G.A.; Nobre, A.D.; Luizão, R.C.; Luizão, F.J. 2004. Evaluation of soil fertility in smallholder agroforestry systems and pastures in western Amazonia. Agriculture, Ecosystems \& Environment, 102: 409-414.

Alves, R.M.; Resende, M.D.V. 2008. Genetic evaluation of individuals and progenies of Theobroma grandiflorum in the state of Pará and estimates of genetic parameters. Revista Brasileira de Fruticultura, 30: 696-701.

Alves, R.M.; Resende, M.D.V.; Bandeira, B.S.; Pinheiro, T.M.; Farias, D.C.R. 2009. Evolução da vassoura-de-bruxa e avaliação da resistência em progênies de cupuaçuzeiro. Revista Brasileira de Fruticultura, 31: 1022-1032.

Alves, R.M.; Resende, M.D.V.; Bandeira, B.S.; Pinheiro, T.M.; Farias, D.C.R. 2010. Avaliação e seleção de progênies de cupuaçuzeiro (Theobroma grandiflorum), em Belém, Pará. Revista Brasileira de Fruticultura, 32: 204-212.

Alves, R.M.; Bastos, A.J.R.; Chaves, S.F.S.; Fernandes, J.R.Q. 2018. Spondias mombin and Theobroma grandiflorum in agroforestry system: productivity implications. Revista Brasileira de Fruticultura, 40: e-061.

Araújo, B.L.; Arnhold, E.; Oliveira Junior, E.A.; Lima, C.F. 2014. Parâmetros genéticos em cultivares de sorgo granífero avaliados em safrinha. Revista Trópica: Ciências Agrárias e Biológicas, 9: 51-59.

Armengot, L.; Barbieri, P.; Andres, C.; Milz, J.; Schneider, M. 2016. Cacao agroforestry systems have higher return on labor compared to full-sun monocultures. Agronomy for Sustainable Development, 36: 70. https://doi.org/10.1007/s13593-016-0406-6-

Barros, A.V.L.; Homma, A.K.O.; Takamatsu, J.A.; Takamatsu, T.; Konagano, M. 2009. Evolução e percepção dos sistemas agroflorestais desenvolvidos pelos agricultores nipo-brasileiros do município de Tomé-Açu, estado do Pará. Amazônia: Ciência \& Desenvolvimento, 5: 121-151.

Beltrame, R.; Bisognin, D.A.; Mattos, B.D.; Cargnelutti Filho, A.; Haselein, C.R.; Gatto, D.A.; Santos, G. A. 2012. Desempenho silvicultural e seleção precoce de clones de híbridos de eucalipto. Pesquisa Agropecuária Brasileira, 47: 791-796.

Bolfe, E.L.; Batistella, M. 2012. Análise florística e estrutural de sistemas silviagrícolas em Tomé-Açu, Pará. Pesquisa Agropecuária Brasileira, 46: 1139-1147.

Castro, A.P; Fraxe, T.J.P.; Santiago, J.L.; Matos, R.B.; Pinto, I.C. 2009. Os sistemas agroflorestais como alternativa de sustentabilidade em ecossistemas de várzea no Amazonas. Acta Amazonica, 39: 279-288.
Condé, T.M.; Lima, M.L.M.; Lima Neto, E.M.; Tonini, H. 2013. Morfometria de quatro espécies florestais em sistemas agroflorestais no munícipio de Porto Velho, Rondônia. Revista Agro@mbiente On-line, 7: 18-27.

Degen, B.; Ward, S.E.; Lemes, M.R.; Navarro, C.; Cavers, S.; Sebben, A.M. 2013. Verifying the geographic origin of mahogany (Swietenia macrophylla King) with DNA-fingerprints. Forensic Science International: Genetics, 7: 55-62.

Drobyshev, I.; Linderson, H.; Sonesson, K. 2007. Relationship between crown condition and tree diameter growth in southern Swedish oaks. Environmental monitoring and assessment 128: 61-73.

EMBRAPA. 2016. Mapas de Solos e de Aptidão Agrícola de Áreas Alteradas do Pará. 1st ed. Embrapa Amazônia Oriental, Belém, $19 \mathrm{p}$.

Fernandes, A.M.V.; Gama, J.R.V.; Rode, R.; Melo, L.O. 2017. Equaçóes volumétricas para Carapa guianensis Aubl. e Swietenia macrophylla King em sistema silvipastoril na Amazônia. Revista Nativa, 5: 73-77.

Florentino, A.T.N.; Araújo, E.L.; Albuquerque, U.P. 2007. Contribuição de quintais agroflorestais na conservação de plantas da Caatinga, Município de Caruaru, PE, Brasil. Acta Botanica Brasilica, 21: 37-47.

Futuyma, D.J. 2009. Coevolution. In: Resh, V.H.; Cardé, R.T. (Ed.). Encyclopedia of Insects. Academic Press, London, p.175-179.

Giustina, C.D.; Carnevalli, R.A.; Romano, M.R.; Antonio, D.B.A.; Eckstein, C. 2017. Growth of different fruit tree species in silvopastoral systems during the establishment phase. Revista Caatinga, 30: 1040-1049.

Gonçalves, A.E.S.S.; Lajolo, F.M.; Genovese, M.I. 2010. Chemical composition and antioxidant/antidiabetic potential of Brazilian native fruits and commercial frozen pulps. Journal of Agricultural and Food Chemistry, 58: 4666-4674.

Grogan, J.; Landis, R.M.; Ashton, M.S.; Galvão, J. 2005. Growth response by big-leaf mahogany (Swietenia macrophylla) advance seedling regeneration to overhead canopy release in southeast Pará, Brazil. Forest Ecology and Management, 204: 399-412.

Grogan, J.; Landis, R.M. 2009. Growth history and crown vine coverage are principal factors influencing growth and mortality rates of big-leaf mahogany Swietenia macrophylla in Brazil. Journal of Applied Ecology, 46: 1283-1291.

Grogan, J.; Loveless, M.D. 2013. Flowering phenology and its implications for management of big-leaf mahogany Swietenia macrophylla in Brazilian Amazonia. American Journal of Botany, 100: 2293-2305.

Liu, W.; Chunjing, Z.; Junen, W.; Chunfeng, C. 2016. Are rubberbased agroforestry systems effective in controlling rain splash erosion?. Catena, 147: 16-24.

Lorenz, K.; Lal, R. 2014. Soil organic carbon sequestration in agroforestry systems. A review. Agronomy for Sustainable Development, 34: 443-454.

Maia, M.C.C.; Resende, M.D.V.; Oliveira, L.C.; Alves, R.M.; Silva Filho, J.L.; Rocha, M.M.; Cavalcante, J.J.V.; Roncatto, G. 2011. Análise genética de famílias de meios-irmãos de cupuaçuzeiro. Pesquisa Florestal Brasileira, 31: 123-130. 
Matheson, A.C.; Lindgren, D. 1985. Gains from the clonal and the clonal seed-orchard options compared for tree breeding programs. Theoretical and Applied Genetics, 71: 242-249.

Motamayor, J.C.; Lachenaud, P.; Mota, J.W.S.; Loor, R.; Kuhn, D.N.; Brown, S.J; Shnell, R J. 2008. Geographic and genetic population differentiation of the Amazonian chocolate tree (Theobroma cacao L.). PloS ONE, 3: e3311.

Pavlidis, G.; Tsihrintzis, V.A. 2018. Environmental benefits and control of pollution to surface water and groundwater by agroforestry systems: a review. Water Resources Management, 32: 1-29.

Poch, T.J.; Simonetti, J.A. 2013. Ecosystem services in human-dominated landscapes: insectivory in agroforestry systems. Agroforestry Systems, 87: 871-879.

Pugliese, A.G.; Tomas-Barberan, F.A.; Truchado, P.; Genovese, M.I. 2013. Flavonoids, proanthocyanidins, vitamin C, and antioxidant activity of Theobroma grandiflorum (Cupuassu) pulp and seeds. Journal of Agricultural and Food Chemistry, 61: 2720-2728.

Regazzi, A.J.; Machado, G.M.E.; Viana, J.M.S.; Cruz, C.D.; Granate, M.J. 2002. Avaliação da divergência genética em uma população amazônica de cupuaçuzeiro (Theobroma grandiflorum (Wild ex Spreng) Schum) por procedimentos multivariados. Ceres, 49: 265-281.

Resende, M.D.V. 2007. Software SELEGEN-REML/BLUP: Sistema Estatístico e Seleção Genética Computadorizada via Modelos Lineares Mistos. 1st ed. Embrapa Florestas, Colombo, 359p.

Resende, M.D.V.; Duarte J.B. 2007. Precisão e controle de qualidade em experimentos de avaliação de cultivares. Pesquisa Agropecuária Tropical, 37: 182-194.

Resende, M.D.V. 2016. Software Selegen-REML/BLUP: a useful tool for plant breeding. Crop Breeding and Applied Biotechnology, 16: 330-339.

Santos, V.S.; Martins Filho, S.; Alves, R.M.; Resende, M.D.V.; Silva, F.F. 2015. Genetic divergence among cupuassu accessions by multiscale bootstrap resampling. Bragantia, 74: 169-175.
Silva, V.A.; Antunes, W.C.; Guimarães, B.L.S.; Paiva, R.M.C.; Silva, V.F.; Ferrão, M.A.G.; Damatta, F.M.; Loureiro, M.E. 2011. Resposta fisiológica de clone de café Conilon sensível à deficiência hídrica enxertado em porta-enxerto tolerante. Pesquisa Agropecuária Brasileira, 45: 457-464.

Souza, A.G.C.; Resende, M.D.V.; Silva, S.E.L.; Sousa, N.R. 2002. The cupuassu genetic improvement program at Embrapa Amazônia Ocidental. Crop Breeding and Applied Biotechnology, 2: 471-478.

Togni, P.H.B.; Frizzas, M.R.; Medeiros, M.A.; Nakasu, E.Y.T.; Pires, C.S.S.; Sujii, E.R. 2009. Dinâmica populacional de Bemisia tabaci biótipo B em tomate monocultivo e consorciado com coentro sob cultivo orgânico e convencional. Horticultura Brasileira, 27: 183-188.

Tonini, H.; Arco-Verde, M.F. 2005. Morfologia da copa para avaliar o espaço vital de quatro espécies nativas da Amazônia. Pesquisa Agropecuária Brasileira, 40: 633-638.

Tschurtschenthaler, N.N.; Vieira, E.S.N.; Nora, T.D.; Schuster, I. 2012. Variabilidade genética de Phakopsora pachyrhizi avaliada por meio de marcadores microssatélites. Pesquisa Agropecuária Brasileira, 47: 181-186.

Utomo, B.; Prawoto, A.A.; Bonnet, S.; Bangviwat, A.; Gheewala, S.H. 2016. Environmental performance of cocoa production from monoculture and agroforestry systems in Indonesia. Journal of Cleaner Production, 134: 583-591.

Venturieri, G.A. 2011. Flowering levels, harvest season and yields of cupuassu (Theobroma grandiflorum). Acta Amazonica, 41: 143-152.

Wallau, R.L.R.; Borges, A.R.; Almeida, D.R.; Camargos, S.L. 2008 Sintomas de deficiências nutricionais em mudas de mogno cultivadas em solução nutritiva. Cerne, 14: 304-310.

RECEIVED: $28 / 02 / 2020$

ACCEPTED: 27/06/2020

ASSOCIATE EDITOR: Alexandre Pio Viana 